\title{
The Effect of Moringa oleifera on Pregnant Women and Breastfeeding Mothers toward Social-personal Development of Children Aged 18-23 Months in Jeneponto, South Sulawesi
}

\author{
Hastuti Hastuti ${ }^{1 *}$, Veni Hadju ${ }^{2}$, Citrakesumasari Citrakesumasari ${ }^{2}$, Martira Maddeppungeng ${ }^{3}$, Ikeu Tanziha ${ }^{4}$, Aryanti Saleh ${ }^{5}$, \\ Karmila Sarih ${ }^{6}$ \\ ${ }^{1}$ Doctoral Student in Public Health, Universitas Hasanuddin, Makassar, Indonesia; ${ }^{2}$ Department of Nutrition, Faculty of Public Health, \\ Universitas Hasanuddin, Makassar, Indonesia; ${ }^{3}$ Departement of Child, Wahidin Sudirohusodo Hospital, Makassar, Indonesia; \\ ${ }^{4}$ Department of Community Nutrition, Institut Pertanian Bogor, Bogor, Indonesia; ${ }^{5}$ Department ofNursing, Nursing Faculty, Universitas \\ Hasanuddin, Makassar, Indonesia; ${ }^{6}$ Department of Nursing, Anging Mammiri Diploma of Nursing, Makassar, Indonesia
}

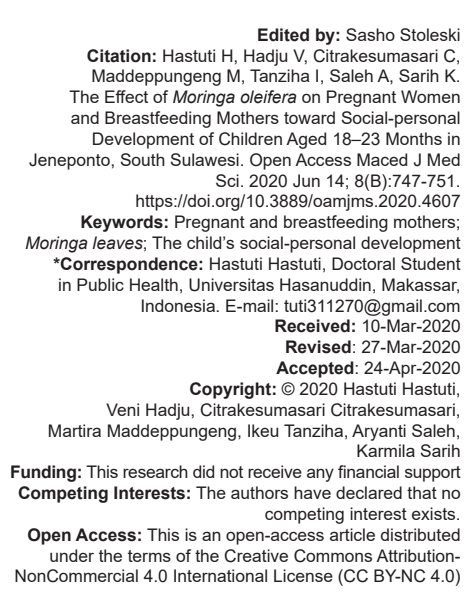

\section{Abstract}

BACKGROUND: Insufficient nutrition intake at the age of <2 years has an impact on decreasing physical growth and development.

AIM: Analyzing the effect of giving Moringa leaves on pregnant women and breastfeeding mothers toward the socia development of children aged 18-23 months in Jeneponto, South Sulawesi.

METHODS: This study was a longitudinal study after supplementation for pregnant women and breastfeeding mothers with Moringa oleifera or folic acid, and iron. Research subjects were children whose was monitored from the age of 18-23 months in Jeneponto District. The number of samples that met the inclusion criteria at the age of 23 months was 344 children. The sample was divided into three groups: A group of children of mothers who got Moringa leaf powder supplements, iron-folic acid supplements, and Moringa leaf extract. Child development was measured using the denver development screening test. Data were analyzed statistically with Chi-square.

RESULTS: There were 107 children (91.5\%) with normal social-personal development in the Moringa leaves powder (MLP) group. This number was more than the children in the iron folic acid (IFA) group of 103 children (86.6\%) and the Moringa leaves extract (MLE) group of 95 children (88.0\%). Differences were also found in the social-personal development of children who were suspect in the IFA group more than children who were suspect in the MLP group or the MLE group.

CONCLUSION: There was no significant difference in children's social-personal development between the three study groups.

\section{Introduction}

Nutrition problems of toddlers and maternal health still require more serious attention. It is shown by the high incidence of malnutrition and poor nutrition reaching $17.7 \%$. Toddler short (stunt) and very short (severely stunted) reach $30.8 \%$, while very skinny and skinny toddlers reach $10.2 \%$. The incidence of chronic energy deficiency in pregnant women is $17.3 \%$, and pregnant women with anemia are $48.9 \%$. The infant mortality rate reaches $24 / 100$ thousand population, and the current maternal mortality ratio reaches $346 / 100$ thousand population, while the 2019 target is 306/100 thousand population [1].

Inadequate nutritional intake, infection, and poor care are direct causes of malnutrition in infants and children. It has an impact not only on macronutrient deficiencies butalso micronutrients that are indispensable for the growth and development of early childhood. The efforts to improve infant nutrition are based on the fact that malnutrition at $<2$ years of age has an impact on reducing physical growth, development, intelligence, and productivity. These impacts are largely irreversible [2].

Micronutrients are needed for brain development during gestation and infancy. This period is substantial for brain development and the formation of a foundation for the development of cognitive, motor, and socioemotional skills during childhood. More than 200 million children aged $<5$ years in low- and middleincome countries have conservative estimates that they do not reach development potential [3].

Children's social-personal development is an aspect related to the ability of independence, socializing, and interacting with the environment. Personal development includes various abilities grouped as habits, personality, character, and emotions. All of them experience changes in their development. The closeness or bonding of infants to adults is subject to the stages of social development. 
The efforts to fulfill micronutrients utilize the potential of local resources to make them easily accessible to the community and are sustainable. One of the potentials of local foodstuffs contains high micronutrients and is widely available but not yet utilized maximally is Moringa oleifera leaves. Moringa is easily found in all parts of Indonesia, including in South Sulawesi.

A research on malnourished communities in Senegal, Africa reports that Moringa leaf flour therapy can significantly improve an individual's nutritional status. The use of Moringa as a source of supplementary food is an effort to overcome malnutrition [4], [5]. Moringa leaves have considerable potential for nutrients, contain a number of amino acids, and several kinds of important micronutrients, such as Vitamin A, Vitamin C, Vitamin E, iron, calcium, zinc, and selenium [6].

To maximize the development of children, especially their social-personal development, it is necessary to conduct a research on the effects of M. oleifera leaves on pregnant women and breastfeeding mothers toward social-personal development of children aged 18-23 months in Jeneponto, South Sulawesi, Indonesia.

\section{Materials and Methods}

\section{Design and location}

This research is a longitudinal study after supplementation for pregnant women and nursing mothers with Moringa oleifera or iron folic acid (IFA) in six sub-districts in Jeneponto Regency which is one of the districts in South Sulawesi with diverse topographic conditions. Some areas are highlands or mountains, and some coastal areas and lowlands.

\section{Participant}

Research subjects were children whose development was monitored from 18 months to 23 months. At the beginning of the study, the total sample was 438 children. The number of samples was reduced because some subjects did not meet the inclusion criteria, refused to participate, moved to other areas which caused researchers to not be able to follow-up. The number of samples that could be measured at 23 months was 344 children.

\section{Procedure}

Several factors related to growth during infancy have previously been measured including family characteristics, maternal conditions during pregnancy and breastfeeding, breastfeeding history, and supplementary feeding. In addition, nutritional care during the 1st year of life is obtained through direct interviews using research forms. Furthermore, children's development was measured using the denver development screening test (DDST).

\section{Instruments}

The DDST is an assessment method that is widely used to assess the development progress of children aged 0-6 years, detect problems in severe child development and as a quick method to identify children who need further evaluation. This test is not a diagnostic test or an intelligence quotient (IQ) test [7]. The DDST consists of developmental task items that are suitable for a child's age from 0 to 6 years old.

\section{Statistical analysis}

The effect of giving Moringa leaves on a child's development was measured using the Chi-square test.

\section{Results}

\section{Characteristics of pregnant and breastfeeding mothers}

Table 1 shows that there are no significant differences in the characteristics of pregnant women and breastfeeding mothers ( $p>0.05$ ). It means that these three research groups have equality or similarity especially in age, frequency of delivery (parity), ante natal care, post-natal care, and mother's knowledge about the benefits of breastfeeding.

Table 1: Characteristics of pregnant and breastfeeding mothers in Jeneponto Regency, 2019

\begin{tabular}{|c|c|c|c|c|c|c|c|c|c|}
\hline \multirow[t]{2}{*}{ Variables } & \multicolumn{2}{|c|}{$\begin{array}{l}\text { MLP } \\
(n=117)\end{array}$} & \multicolumn{2}{|c|}{$\begin{array}{l}\text { IFA } \\
(n=119)\end{array}$} & \multicolumn{2}{|c|}{$\begin{array}{l}\text { MLE } \\
(n=108)\end{array}$} & \multicolumn{2}{|c|}{$\begin{array}{l}\text { Total } \\
(\mathrm{n}=344)\end{array}$} & \multirow[t]{2}{*}{$\mathrm{p}^{*}$} \\
\hline & $\mathrm{n}$ & $\%$ & $\mathrm{n}$ & $\%$ & $\mathrm{n}$ & $\%$ & $\mathrm{n}$ & $\%$ & \\
\hline \multicolumn{10}{|l|}{ Mother's age } \\
\hline $20-35$ yo & 86 & 73.5 & 82 & 68.9 & 79 & 73.1 & 247 & 71.8 & \multirow[t]{2}{*}{0.685} \\
\hline$<20$ and $>35$ yo & 31 & 26.5 & 37 & 31.1 & 29 & 26.9 & 97 & 28.2 & \\
\hline \multicolumn{10}{|l|}{ Parity } \\
\hline 1 & 31 & 26.5 & 46 & 38.7 & 31 & 28.7 & 108 & 31.4 & \multirow[t]{2}{*}{0.101} \\
\hline$>1$ & 86 & 73.5 & 73 & 62.3 & 77 & 71.3 & 236 & 68.6 & \\
\hline \multicolumn{10}{|c|}{ Ante natal care (times) } \\
\hline$<4$ & 64 & 54.7 & 80 & 67.2 & 72 & 66.7 & 216 & 62.8 & \multirow[t]{2}{*}{0.083} \\
\hline$>4$ & 53 & 45.3 & 39 & 32.8 & 36 & 33.3 & 128 & 37.2 & \\
\hline \multicolumn{10}{|l|}{ Post-natal care } \\
\hline Yes & 24 & 20.5 & 32 & 26.9 & 22 & 20.4 & 78 & 22.7 & \multirow[t]{2}{*}{0.397} \\
\hline No & 93 & 79.5 & 87 & 73.1 & 86 & 79.6 & 266 & 77.3 & \\
\hline \multicolumn{10}{|c|}{ Benefits of breastfeeding } \\
\hline Aware & 78 & 66.7 & 89 & 74.8 & 72 & 66.7 & 239 & 69.5 & \multirow[t]{2}{*}{0.298} \\
\hline Not aware & 39 & 33.3 & 30 & 25.2 & 36 & 33.3 & 105 & 30.5 & \\
\hline
\end{tabular}

\section{Child characteristics}

Table 2 shows that the birth length of children is significant in all three groups $(p=0.034)$ but there are no significant differences in sex, birth weight, birth process, 
place of birth, colostrum, prelacteal, breastfeeding, complementary feeding, and immunization between the three research groups $(p>0.05)$. It illustrates that the three groups of research subjects have similarities in terms of gender, birth weight, birth process, place of birth, colostrum, prelacteal, breastfeeding, complementary feeding, and immunization.

Table 2: Characteristics of children aged 18-23 months in Jeneponto Regency, 2019

\begin{tabular}{|c|c|c|c|c|c|c|c|c|c|}
\hline \multirow[t]{2}{*}{ Variables } & \multicolumn{2}{|c|}{$\operatorname{MLP}(n=117)$} & \multicolumn{2}{|c|}{ IFA $(n=119)$} & \multicolumn{2}{|c|}{ MLE $(n=108)$} & \multicolumn{2}{|c|}{ Total $(n=344)$} & \multirow[t]{2}{*}{$\mathrm{p}^{*}$} \\
\hline & $\mathrm{n}$ & $\%$ & $\mathrm{n}$ & $\%$ & $\mathrm{n}$ & $\%$ & $\mathrm{n}$ & $\%$ & \\
\hline \multicolumn{10}{|l|}{ Sex } \\
\hline Male & 64 & 54.7 & 66 & 55.5 & 60 & 55.6 & 190 & 55.2 & \multirow[t]{2}{*}{0.990} \\
\hline Female & 53 & 45.3 & 53 & 44.5 & 48 & 44.4 & 154 & 44.8 & \\
\hline \multicolumn{10}{|l|}{ Birth weight } \\
\hline$\geq 2500$ & 114 & 97.4 & 111 & 93.3 & 104 & 96.3 & 329 & 95.6 & \multirow[t]{2}{*}{0.271} \\
\hline$<2500$ & 4 & 2.6 & 8 & 6.7 & 4 & 3.7 & 15 & 4.4 & \\
\hline \multicolumn{10}{|l|}{ Birth length } \\
\hline$\geq 48 \mathrm{~cm}$ & 105 & 89.7 & 93 & 78.2 & 94 & 87.0 & 292 & 84.9 & \multirow[t]{2}{*}{$0.034^{*}$} \\
\hline$<48 \mathrm{~cm}$ & 12 & 10.3 & 26 & 21.8 & 14 & 13.0 & 52 & 15.1 & \\
\hline \multicolumn{10}{|l|}{ Birth process } \\
\hline Normal & 114 & 97.4 & 111 & 93.3 & 99 & 91.7 & 324 & 94.2 & \multirow[t]{2}{*}{0.158} \\
\hline Section secaria & 3 & 2.6 & 8 & 6.7 & 9 & 8.3 & 20 & 5.8 & \\
\hline \multicolumn{10}{|l|}{ Place of birth } \\
\hline Medical facility & 106 & 90.6 & 107 & 89.9 & 102 & 94.4 & 314 & 91.3 & \multirow[t]{2}{*}{0.371} \\
\hline House & 11 & 9.4 & 12 & 10.1 & 6 & 5.6 & 30 & 8.7 & \\
\hline \multicolumn{10}{|l|}{ Colostrum } \\
\hline Yes & 105 & 89.7 & 107 & 89.9 & 102 & 94.4 & 314 & 91.3 & \multirow[t]{2}{*}{0.371} \\
\hline No & 12 & 10.3 & 12 & 10.1 & 5 & 5.6 & 30 & 8.7 & \\
\hline \multicolumn{10}{|l|}{ Prelacteal } \\
\hline No & 90 & 76.9 & 88 & 73.9 & 84 & 77.8 & 262 & 76.2 & \multirow[t]{2}{*}{0.774} \\
\hline Yes & 27 & 23.1 & 31 & 26.1 & 24 & 22.2 & 82 & 23.8 & \\
\hline \multicolumn{10}{|l|}{ Breastfeeding } \\
\hline Exclusive & 55 & 47.0 & 58 & 48.7 & 49 & 45.4 & 162 & 47.1 & \multirow[t]{2}{*}{0.879} \\
\hline Non exclusive & 62 & 53.0 & 61 & 51.3 & 59 & 54.6 & 182 & 52.9 & \\
\hline \multicolumn{10}{|c|}{ Complementary feeding (months) } \\
\hline$\geq 6$ & 84 & 71.8 & 93 & 78.2 & 77 & 71.3 & 254 & 73.8 & \multirow[t]{2}{*}{0.415} \\
\hline$<6$ & 33 & 28.2 & 26 & 21.8 & 31 & 28.7 & 90 & 26.2 & \\
\hline \multicolumn{10}{|l|}{ Immunization } \\
\hline Complete & 66 & 56.4 & 52 & 43.7 & 51 & 47.2 & 169 & 49.1 & \multirow[t]{2}{*}{0.132} \\
\hline Incomplete & 51 & 43.6 & 67 & 56.3 & 57 & 52.8 & 175 & 50.9 & \\
\hline
\end{tabular}

\section{Socioeconomic characteristics of family}

The results of statistical analysis show that there are no significant differences in mother's and father's education, mother's and father's occupation, and monthly family income between the three study groups $(p>0.05)$. Table 3 illustrates that the three research groups have similarities in terms of your education, your work, and monthly family income.

Table 3: Socioeconomic characteristics of family in Jeneponto Regency, 2019

\begin{tabular}{|c|c|c|c|c|c|c|c|c|c|}
\hline \multirow[t]{2}{*}{ Variables } & \multicolumn{2}{|c|}{$\begin{array}{l}\text { MLP } \\
(n=117)\end{array}$} & \multicolumn{2}{|c|}{$\begin{array}{l}\text { IFA } \\
(n=119)\end{array}$} & \multicolumn{2}{|c|}{$\begin{array}{l}\text { MLE } \\
(n=108)\end{array}$} & \multicolumn{2}{|c|}{$\begin{array}{l}\text { Total } \\
(\mathrm{n}=344)\end{array}$} & \multirow[t]{2}{*}{$p^{*}$} \\
\hline & $\mathrm{n}$ & $\%$ & $\mathrm{n}$ & $\%$ & $\mathrm{n}$ & $\%$ & $\mathrm{n}$ & $\%$ & \\
\hline \multicolumn{10}{|c|}{ Mother's education (years) } \\
\hline$\geq 12$ & 38 & 32.5 & 35 & 29.4 & 32 & 29.6 & 105 & 30.5 & 0.852 \\
\hline$<12$ & 79 & 67.5 & 84 & 70.6 & 76 & 70.4 & 239 & 69.5 & \\
\hline \multicolumn{10}{|c|}{ Father's education (years) } \\
\hline$\geq 12$ & 45 & 38.5 & 36 & 30.3 & 30 & 27.8 & 111 & 32.3 & 0.195 \\
\hline$<12$ & 72 & 61.5 & 83 & 69.7 & 78 & 72.2 & 233 & 67.7 & \\
\hline \multicolumn{10}{|l|}{ Mother's occupation } \\
\hline Employed & 26 & 22.2 & 25 & 21.0 & 19 & 17.6 & 70 & 20.3 & 0.673 \\
\hline Unemployed & 91 & 77.8 & 94 & 79.0 & 89 & 82.4 & 274 & 79.7 & \\
\hline \multicolumn{10}{|l|}{ Father's occupation } \\
\hline Farmers + Fishermen & 50 & 42.7 & 53 & 44.5 & 46 & 42.6 & 149 & 43.3 & 0.395 \\
\hline Civil servants/private & 14 & 12.0 & 18 & 15.1 & 20 & 18.5 & 52 & 15.1 & \\
\hline Driver/labor & 36 & 30.8 & 24 & 20.2 & 27 & 25.0 & 87 & 25.3 & \\
\hline Entrepreneur & 14 & 12.0 & 22 & 18.5 & 11 & 10.2 & 47 & 13.7 & \\
\hline Others & 3 & 2.6 & 2 & 1.7 & 4 & 3.7 & 9 & 2.6 & \\
\hline \multicolumn{10}{|c|}{ Family income (million/mo) } \\
\hline$\geq 2$ & 29 & 24.8 & 32 & 26.9 & 31 & 28.7 & 92 & 26.7 & 0.802 \\
\hline$<2$ & 88 & 75.2 & 87 & 73.1 & 77 & 71.3 & 252 & 73.3 & \\
\hline
\end{tabular}

\section{Social-personal development of children} aged 18-23 months

Table 4 shows that there are 107 children $(91.5 \%)$ with normal social-personal development in the Moringa leaves powder (MLP) group; this number is more than the children in the IFA group which are 103 children (86.6\%) and the Moringa leaves extract (MLE) group which are 95 children (88.0\%).

Table 4: Social-personal development of children aged 18-23 months between MLP, IFA, and MLE groups in Jeneponto Regency, 2019

\begin{tabular}{|c|c|c|c|c|c|c|c|c|c|}
\hline \multirow[t]{2}{*}{ Child's social-personal } & \multicolumn{2}{|c|}{ MLP } & \multicolumn{2}{|l|}{ IFA } & \multicolumn{2}{|c|}{ MLE } & \multicolumn{2}{|c|}{ Total } & \multirow[t]{2}{*}{$p$-value } \\
\hline & $\mathrm{n}$ & $\%$ & $\mathrm{n}$ & $\%$ & $\mathrm{n}$ & $\%$ & $\mathrm{n}$ & $\%$ & \\
\hline \multicolumn{10}{|l|}{ Social-personal } \\
\hline Normal & 107 & 91.5 & 103 & 86.6 & 95 & 88.0 & 305 & 88.7 & 0.476 \\
\hline Suspect & 10 & 8.5 & 16 & 13.4 & 13 & 12.0 & 39 & 11.3 & \\
\hline
\end{tabular}

The differences are also seen in the social development of suspect children. It turns out that the number of children with suspect development in the IFA group is more than those who are suspect in the MLP group or the MLE group.

It shows that social-personal development in children from the MLP and MLE groups has a better tendency than children from the IFA group. Although the results of statistical tests showed that there was no significant difference [Figure 1], the MLP and MLE groups were empirically more likely to be better than the IFA group.

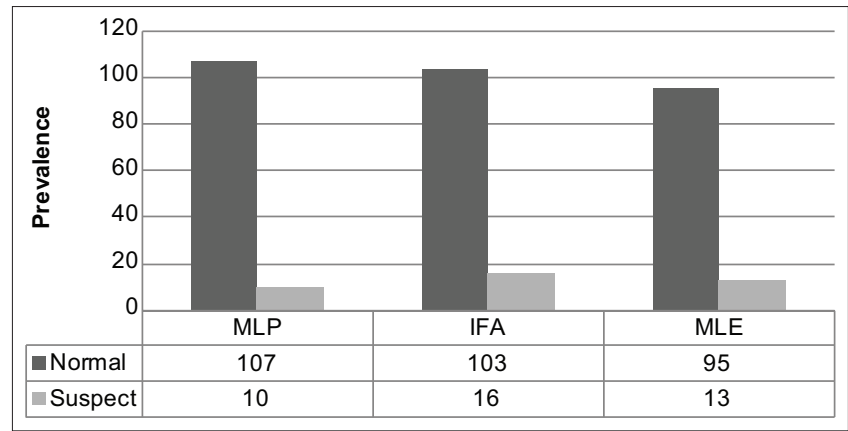

Figure 1: Social-personal development children aged 18-23 months between the Moringa leaves powder, iron folic acid, and Moringa leaves extract groups in Jeneponto Regency, 2019

\section{Discussion}

The results showed that social-personal development of the children from the MLP and MLE groups tended to be better than the children from the IFA group; although the results of statistical tests showed no significant difference $(p>0.05)$.

The results of the study using prescreening developmental questionnaire found that of 321 subjects aged 1-2 years, there were 278 children $(90.22 \%)$ who experienced normal development and 30 children $(9.78 \%)$ experienced suspect development [8]. If 
children who experience these developmental disorders are not handled properly, the majority of them (89\%) will experience failure in their schools. In developing countries, including Indonesia, environmental factors that can cause child developmental disorders are generally caused by poverty and people's ignorance of the process of growth and development [9].

A research on the development of toddlers aged 7-24 months between children who were given exclusive and non-exclusive breastfeeding in Ngawi District found that the social-personal development of children who received exclusive breastfeeding was better than children who did not receive exclusive breastfeeding [10]. The content of zinc in breast milk is needed for growth and development, the immune system and the prevention of certain diseases in infants. Growth and development can work with the help of exclusive breastfeeding such as gross motor skills, fine motor skills, speech and language skills, as well as the ability to socialize and being independent [11].

There is $5.20 \mathrm{mg}$ of zinc in $100 \mathrm{mg}$ of Moringa flour consumed by breastfeeding mothers which is expected to have an effect on the content of breast milk. Zinc is an important mineral for children's growth and development. Zinc minerals play a role in protein synthesis, adenosine dinucleoside (DNA), and adenosine ribonucleoside (RNA) and play a role in the work of enzymes in the body. Zinc deficiency will be fatal, especially in the development of brain structure, brain function, and interfere with behavioral and emotional responses. Moringa supports brain health and cognitive function with antioxidant and neuroenhancer activities. Moringa leaf powder has a positive effect on the prevention and control of malnutrition in infants, pregnant women, and breastfeeding mothers [12].

At the age of 1-2 years, most children still receive total attention from their mothers regarding their food, breast milk, and adequate development stimulation. Giving total breast milk will strengthen the mental relationship between mother and child that is very beneficial for further development of mental and emotional of the children [13].

The growth and development disorders of children can occur within a period of growth and development processes that take place from intrauterine to adulthood. Influencing factors include genetic, environmental, and disease factors experienced by children. Early detection and appropriate interventions can optimize the quality of subsequent child development [14].

One of the appropriate intervention efforts to improve the nutrition of pregnant women and breastfeeding mothers which ultimately maximizes the growth and development of children is to utilize local potential. One of the many local potential available in South Sulawesi is Moringa leaves. Moringa leaves are the food that is rich in macro- and micro-nutrients. The high nutritional value in the Moringa leaves can be used to meet the nutritional needs of breastfeeding mothers and toddlers in their infancy [15].

Children's development patterns can be disrupted not only from environmental or physical conditions in the form of nutritional deficiencies whether temporary or permanent, but the developmental disorders can be in the form of illness, seasons, or severe emotional tension [16].

Not all children experience normal socialpersonal development. It can be caused partly by the mother's age, educational background, type of work and family income per month, cultural values, lifestyle, social, and family values [17]

The responsibility of parenting especially mothers in providing stimulation is based on the knowledge that is owned by the mother, but the knowledge and skills possessed by the mother are frequently inadequate. It can be due to mother's education level.

One of the factors that can affect a child's social-personal disorders in this study is the level of parents' education. Most parents have education $<12$ years. Someone with a high level of education has more knowledge. Knowledge obtained from the education is applied in everyday life, especially in the provision of stimulation to the children. Parents can receive all information about how to take care of the children well with stimulation, and how to maintain the health of their children. Lack of education will interfere the development of someone's attitude toward newly introduced values, which causes mothers to be unable to provide stimulatory measures optimally [18].

Some experts associate the causes of developmental disorders of children against the background of poverty; it is related to family income. In this study, the monthly family income was < IDR $2,000,000$ which means the family's economic status was low. Type of work and income per month is the two factors that can affect the provision of stimulation.

Factors of poverty and life pressure can cause a person to easily emit emotions to those around him/her, including children. Work factors related to economic conditions are closely related to the cause of parents doing verbal abuse due to the increasing number of crises in their lives. It causes the non-optimal stimulation of children [19].

Another factor causing suspect of the child's social-personal development in this study was the age of the parents. The majority of them were middleaged adults, 20-35 years, who had considerable developmental tasks, just started working, learned to live with their husband or wife, started having new families, taking care of children, and managing households. Parents should continue to accompany the children at each stage of their growth and development, and train their social-personal development by introducing them 
to new activities such as playing with other children, showing affection for toys, other children, siblings or pets. Parents should ensure that children do it in their own way with parental supervision. Stimulation given by parents is related to the child's behavior, mediated by positive parenting practices [20].

During the children's development, social support from family members is an important factor that can encourage them to behave positively. The better the stimulation a parent gives to a child, the better the child's social-personal development.

\section{Conclusion}

We concluded that there was no significant difference in the children's social-personal development between the three study groups.

\section{References}

1. Kementerian Kesehatan. Data Riset Kesehatan Dasar, Riskesdas. Jakarta: Kementerian Kesehatan; 2018.

2. Badan Perencanaan Pembangunan Nasional. Rencana Aksi Nasional Pangan dan Gizi Tahun 2011-2015. Jakarta: Badan Perencanaan Pembangunan Nasional; 2011.

3. Zakaria Z, Hadju V, As'ad S, Bahar B. The effect of Moringa leaf extract in breastfeeding mothers against anemia status and breast milk iron content. Int J Sci Basic Appl Res. 2015;24(1):321-9.

4. Prado EL, Alcock KJ, Muadz H, Ullman MT, Shankar AH. Maternal multiple micronutrient supplements and child cognition: A randomized trial in Indonesia. Pediatrics. 2012;130(3):e53646. https://doi.org/10.1542/peds.2012-0412

\section{PMid:22908103}

5. Nadimin N, Hadju V, As'ad S, Buchari A. The extract of Moringa leaf has an equivalent effect to iron folic acid in increasing hemoglobin levels of pregnant women: A randomized control study in the coastal area of Makassar. Int J Sci Basic Appl Res. 2015;22(1):287-94. https://doi. org/10.5958/0976-5506.2019.00102.5
6. Fuglie LJ. The Moringa Tree: A Lokal Solution to Malnutrition. Senegal: Church World Service; 2005.

7. Soetjiningsih S. Tumbuh Kembang Anak. Jakarta: Penerbit Buku Kedokteran, EGC; 2014.

8. Gunawan G, Fadlyana E, Rusmil K. Hubungan status giz dan perkembangan anak usia 1-2 tahun. Sari Pediatr. 2016;13(2):142-6. https://doi.org/10.14238/sp13.2.2011.142-6

9. Fadlyana E, Alisjahbana A, Nelwan I, Noor M, Selly S, Sofiatin Y Pola Keterlambatan perkembangan balita di daerah pedesaan dan perkotaan bandung, serta faktor-faktor yang mempengaruh. Sari Pediatr. 2003;4(4):168-75. https://doi.org/10.14238/ sp4.4.2003.168-75

10. Astutik. RY. Payudara dan Laktasi. Jakarta: Salemba Medika 2014. p. 12-3.

11. Saraswati A, Muwakhidah M. Perkembangan Motorik antara BALITA Usia 7-24 bulan ASI eksklusif dan non ASI eksklusif DI puskesmas mantingan kabupaten Ngawi. J Kesehatan. 2018;11(1):24-31. https://doi.org/10.37413/jmakia.v6i1.14

12. Rahayu TB, Nurindahsari YA. Peningkatan Status Gizi BALITA melalui pemberian daun kelor (Moringa oleifera). J Kesehatan Madani Med. 2018;9(2). https://doi.org/10.36569/jmm.v9i2.14

13. Widuri H. Cara Mengolah ASI Ekslusif Bagi Ibu Bekerja. Yogyakarta: Gosyen Publising; 2013.

14. Irwanto I, Suryawan MB. Penyimpangan Tumbuh Kembang Anak. Divisi Tumbuh Kembang Anak dan Remaja Bagian IImu Kesehatan Anak. Surabaya: Kapita Selekta IImu Kesehatan Anak Vl; 2006. https://doi.org/10.31219/osf.io/3j9qb

15. Hidayat AA. Pengantar IImu Keperawatan Anak. Jakarta: Medical Journal of Indonesia; 2005.

16. Hurlock EB. Psikologi Perkembangan, Suatu Pendekatan Sepanjang Rentang Kehidupan (Terjemahan). Jakarta: Erlangga; 2012.

17. Makhfudli $\mathrm{P}$, Rachmawati R, Andini S. Factors related to open defecation behavior among school-age children in West Lombok. J Ners. 2017;12:119-25. https://doi.org/10.20473/ jn.v12i1.4028

18. Soetjiningsih S. Tumbuh Kembang Anak. Jakarta: Penerbit Buku Kedokteran, EGC; 2012.

19. Serrano-Villar M, Huang KY, Calzada JE. Social support, parenting, and social emotional development in young mexican and dominican American children. Child Psychiatry Hum Dev. 2017;48(4):597-609. https://doi.org/10.1007/ s10578-016-0685-9

PMid:27696243

20. Leyendecker G, Bilgicyildirim A, Huppert P, Wildt G, Bottcher BL. Adenomyosis and endometriosis. Re-visiting their association and further insights into the mechanisms of auto-traumatisation. An MRI study. Arch Gynecol Obstet. 2015;291(4):917-32. https://doi.org/10.1007/s00404-014-3437-8

PMid:25241270 